\title{
Chalcone Synthase: Method Optimization of Extraction and Activity Assay in Strawberry Fruit
}

\author{
Linda Ines Zoungrana, Alyssa N. Smith and M. Cecilia do Nascimento Nunes
}

Food Quality Laboratory, Department of Cell Biology, Microbiology and Molecular Biology, University of South Florida, Tampa, USA

\section{ABSTRACT}

Method development and optimization play a central role in analytical chemistry and more specifically in food biochemistry. When it comes to research, it is common that analytical methods need to be modified to specific experimental biological tissues. While there are several published works on the activity of the enzyme chalcone synthase (CHS) in plant materials, such as sweet basil using ultrahigh-performance liquid chromatography, there is a lack of information regarding extraction and activity of $\mathrm{CHS}$ in strawberries. Therefore, the main objective of this work was to optimize existing published methods for extraction and activity of $\mathrm{CHS}$ in strawberries, using spectrophotometric analysis. It was done through a literature search, a method dissection was performed, followed by theoretical optimization of the protocol, and finally a experimental optimization.

\section{INTRODUCTION}

Chalcone synthase is a ubiquitous enzyme in higher plants. It catalyzes the sequential decarboxylative addition of three acetate units from malonyl-CoA to a $p$-coumaroyl-CoA starter molecule deriving from phenylalanine through the phenylpropanoid pathway ${ }^{1}$, which is a rich source of metabolites in plants ${ }^{2}$. While there are several published works on the activity of the enzyme chalcone synthase (CHS) in plant materials, such as sweet basil using ultra- high-performance liquid chromatography, there is a lack of information regarding extraction and activity of $\mathrm{CHS}$ in strawberries. From the literature search we based our method optimization on the work published by Ghasemzadeh et al. (2016) on sweet basil using spectrophotometry and ionic exchange reasin rather than HPLC. This protocol was analyzed and adjusted for strawberry fruit.

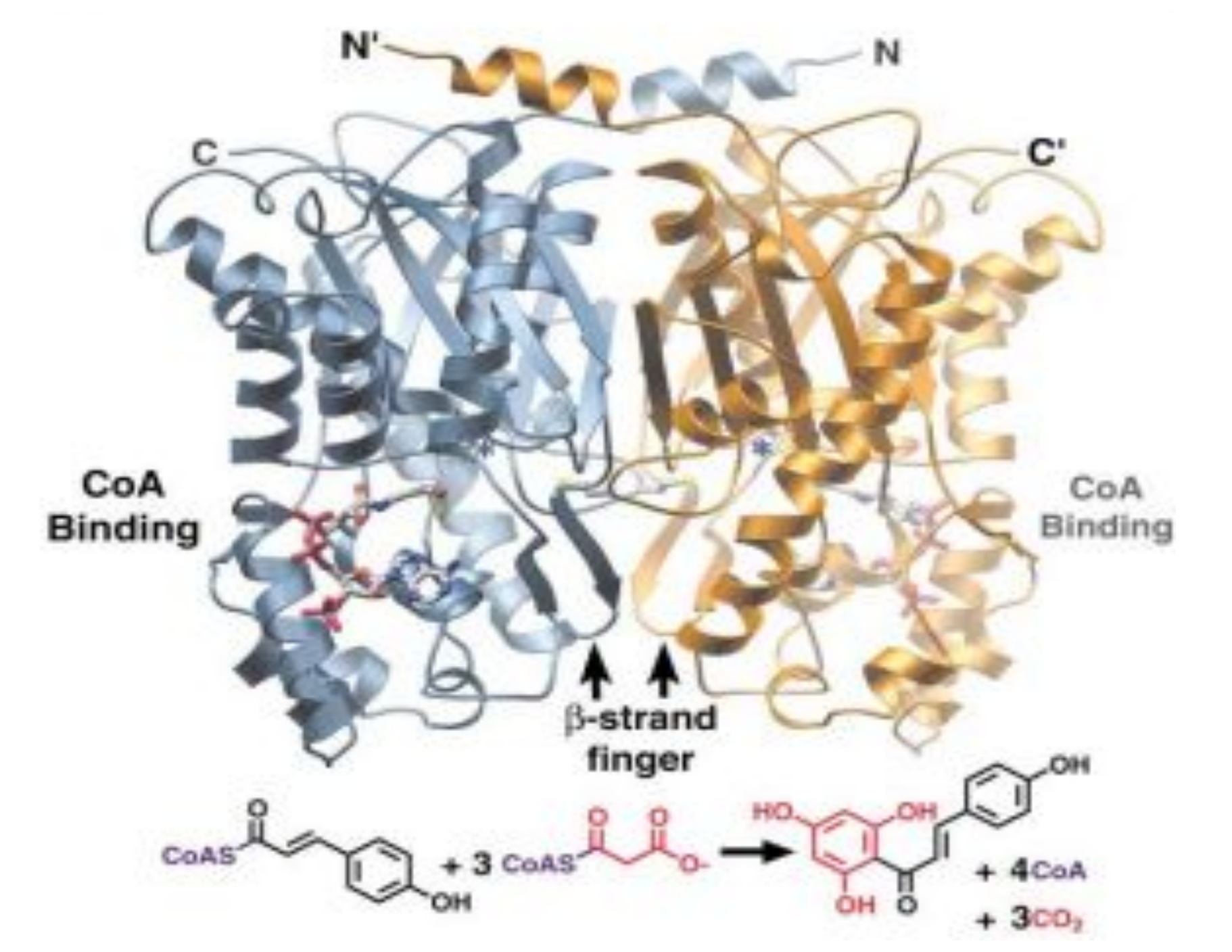

Fig 1: Structure, CoA binding, and overall reaction of chalcone synthase (CHS). Each cotalyzed by CHS with the malonyl derived portions of chalcone shown in red (Austin al., 2003)

\section{MATERIAL AND METHODS}

Strawberry fruit will be homogenized and $0.4 \mathrm{~g}$ of fruit puree will be mixed with a solution of $40 \mathrm{mg}$ of 2-mercaptoethanol dissolved in $500 \mathrm{~mL}$ of $0.1 \mathrm{M}$ borate buffer at $4{ }^{\circ} \mathrm{C}$

Borate Buffer will be prepared as follows:

a $3.1 \mathrm{~g}$ of boric acid plus $300-400 \mathrm{~mL}$ of D.I. water

a $1 \mathrm{~mol}$ of $\mathrm{NaOH}$ to adjust the $\mathrm{pH}$ to around 8

$0.1 \mathrm{~g}$ of Dowex $\mid \times 4$ resin will be added to the solution, for ion exchange and lower the reaction time

To the supernatant $100 \mathrm{~mL}$ of $10 \mathrm{mM}$ of potassium cyanide and $500 \mathrm{~mL}$ of $1 \mathrm{M}$ of Tris-HCl buffer will be added. $10 \mathrm{mg}$ of chalcone will be added to $10 \mathrm{uL}$ ethylene glycol monomethyl ether, mixed with enzyme extract, and left at for $1 \mathrm{~min}$ at $30 \circ \mathrm{C}$.

The absorbance will be measured at $370 \mathrm{~nm}$.

The final protocol will be tested, with some possible further modification, such as adjustment of sample size, the volume or the concentration of each solution and temperature.

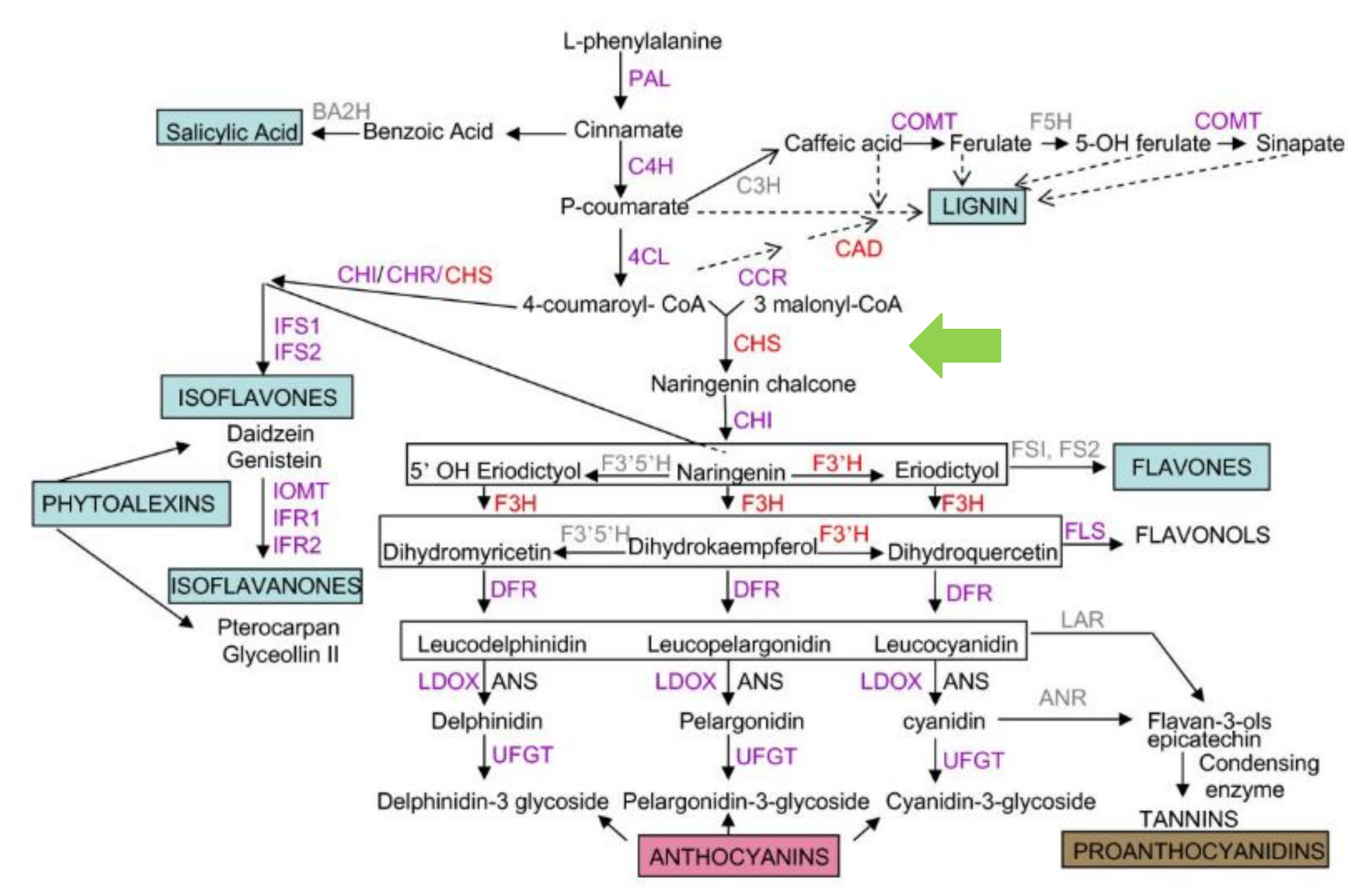

Fig 2: Phenylpropanoid metabolic pathway. Enzyme activity and interaction present in the pathways (Zabala et al., 2006)

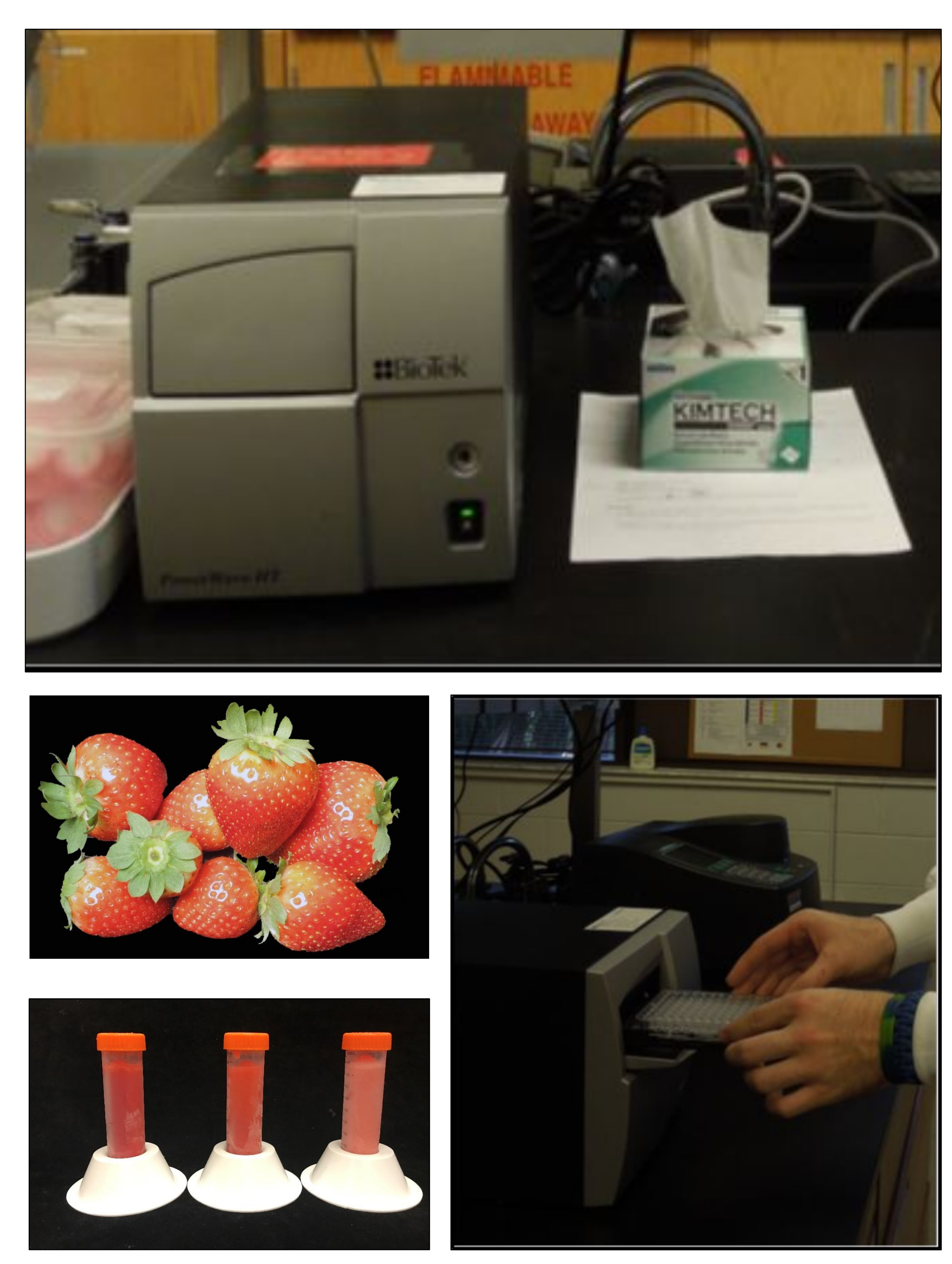

\section{REFERENCES}

1) Austin, M. B., \& Noel, J. P. (2003). The Chalcone Synthase Superfanly or \&ype 31 Polyketide Synthases. Chem/nform,34(17).

e, C. (n.d.). The phenylpropanoid pathway in https://www.ncbi.nlm.nih.gov/pmc/articles/PMC3268504/

3) Fehr, D. (2006). AopP, a type III effector protein of Aeromonas salmonicida, inhibits the NF-B signalling pathway. Microbiology, 152(9), 2809-2818. doi:10.1099/mic.0.28889-0 Ghasemzadeh, A., Ashkani, S., Baghdadi, A., Pazoki, A., Jaafar, H., 8 Rahmat, A. (2016). Improvenent have basilicum and by Ultraviolet-B Irradiation. Molecules.21(9), 1203 doi:10.3390/molecules21091203

5) Kreuzaler F, Hahlbrock K (November 1972). "Enzymatic synthesis of aromatic compounds in higher plants: formation of naringenin (5,7,4'trihydroxyflavanone) from p-coumaroyl coenzyme $A$ and malonyl coenzyme A. FEBS Lett. 28 (1). 69-72.

6) Koundal, K. R., Sawhney, S. K. and Sinha, S. K. (1983) (n) 2183

7) Rose, R. C. and Nahrwold, D. L. (1982) Analyt. Biochem. 123389.

8) Schriider, J., Heller, W. and Hahlbrock, K. (1979) Plant Sci. Letters

9) Zabala, G., Zou, J., Tuteja, J., Gonzalez, D. O., Clough, S. J., doi:10.1186/1471-2229-6-26 